\title{
EFFECT OF ANTIBIOTIC AND SULPHONAMIDE TREATMENT ON THE DEVELOPMENT OF POST-VACCINATION IMMUNITY TO TRICHOPHYTOSIS IN CATTLE
}

\author{
A. RYBNIKÁR, ${ }^{1}$ J. KUJA, ${ }^{2}$ J. PETRÁS̆ ${ }^{3}$ and V. VRZAL ${ }^{1}$ \\ Bioveta, 68323 Ivanovice na Hané, ${ }^{1}$ District Veterinary Administration, 68200 Vyškov, ${ }^{2}$ Institute \\ for State Control of Veterinary Biologicals and Drugs, $62100 \mathrm{Brno}^{3}$
}

Received fuly 24, 1990

\begin{abstract}
Rybnikár̆ A., J. Kuja, J. Petráš, V. Vrzal: Effect of Antibiotic and Sulphonamide Treatment on the Development of Post-Vaccination Immunity to Trichophytosis in Cattle. Acta vet. Brno, 60, 1991: 351-356.

Calves treated with chloramphenicol or apramycin at the time of vaccination against trichophytosis were less resistant to experimental infection with Trichophyton verrucosum culture than vaccinated calves not treated with these antibiotics. Treatment with preparations containing penicillin, streptomycin, oxytetracycline, rolitetracycline, tylosine or sulphonamide had no immunosuppressive effect on the development of post-vaccination immunity.
\end{abstract}

Trichophyton verrucosum, vaccination, antibiotics, sulphonamides, immunosuppression

Immunosuppressive efects of some antibiotics have been reported (Nouza and Joun 1987; Vrtiak 1990). According to Kanjuka and Sutiak (1990) antibiotics suppress the immune response of animals to living bacteria and also slow down the production of artificial immunity. We thought it of interest to find to which extent treatment with antibiotics or sulphonamides would affect the post-vaccination immunity of cattle to a dermal mycotic disease, bovine trichophytosis.

\section{Materials and Methods}

The experimental animals were 1-month-old calves of the Bohemian Pied Breed coming from herds without a history of trichophytosis. They were in good nutritional and health status.

In each experiment one or two antibiotics or sulphonamide were tested by administering them to calves at the time of their vaccination against trichophytosis. The results were compared with those obtained in vaccinated calves receiving no antibiotic or sulphonamide treatment.

The experimental animals were injected i.m. with the following preparations in doses given per $\mathrm{kg}$ body mass per day for 5 days: Penstrepten inj. (benzylpenicillium $10000 \mathrm{IU} . \mathrm{kg}^{-1}$, dihydrostreptomycinum sulfuricum $100 \mathrm{mg} \cdot \mathrm{kg}^{-1}$; active ingredients: penicillin and streptomycin), Biopran 200 inj. (20 mg . kg-1; active ingredient: apramycin), Chronicin inj. (12 mg . $\mathrm{kg}^{-1}$; active ingredient: D-chloramphenicol), Oxymycoin inj. ( $8 \mathrm{mg} . \mathrm{kg}^{-1}$; active ingredient: oxytetracycline), Rolitetracyclin inj. (10 mg . kg-1; active ingredient: rolitetracycline), Tylan 200 inj. (100 mg . kg active ingredient: tylosine) and Duon inj. (sulfadimidinum natricum $395 \mathrm{mg} \cdot \mathrm{kg}^{-1}$, trimethoprimum $80 \mathrm{mg} . \mathrm{kg}^{-1}$ ).

At the time of the last injection with one of the afore-mentioned preparations the calves were vaccinated with prophylactic doses of lyophilized vaccine against bovine trichophytosis (manufactured by Bioveta, Ivanovice na Hané). Vaccinated at the same time were further calves that received no antibiotic or sulphonamide treatment. All these groups were revaccinated 14 days later. One month afterwards all the vaccinated calves and non-vaccinated controls were challenged with a virulent culture of Trichcphyton verrucosum by epicutaneous inoculation of the suspension onto a $10 \times 10 \mathrm{~cm}$ clipped and gently scarified area of the right flank at the rate of 4 to 5 million conidia per animal and then observed for 32 days. Any clinical dermal lesions observed were examined microscopically and by culture at the end of the experiment. 


\section{Results}

The results are presented in Tables 1 to 6 . It can be seen that the calves vaccinated against trichophytosis without previous antibiotic treatment proved highly resistant to experimental trichophytosis. In these animals dermal changes at the challenge site were either absent at all or were only slight and of short duration. At the end of the experiment ( 32 days after challenge) no signs of trichophytosis were observed in any of these animals. Similar results were obtained in those vaccinated calves that were treated with Oxymycoin, Penstrepten, Rolitetracycline, Tylan or Duon at the time of vaccination.

The degree of protection conferred by vaccination to calves treated with Chronicin or Biopran was lower than in the preceding groups: throughout the experiment the proportions of clinically diseased animals were higher than in the groups of vaccinated calves that received no antibiotic treatment. At the end of the experiment 2 out of 10 Biopran-treated calves were clinically ill and 1 animal showed a dubious reaction. Out of 21 Chronicin-treated calves 2 developed clinical signs of trichophytosis and 2 animals showed dubious reactions.

All the control non-vaccinated and challenged calves developed marked trichophytic crusts that merged to continuous lesions and persisted till the end of the experiment without any tendency to self-healing.

The results of examination by culture and of microscopic examination were in keeping with the clinical findings: they demonstrated the challenge strain in clinically positive animals and were negative in calves showing no signs of trichophytosis.

\section{Discussion}

Practical experience reported by Gorobec (1972) showed that further immunoprophylactic treatment of cattle at the time of their vaccination against trichophytosis had a negative effect on the development of immunity against this disease. Immunosuppressive effects were observed particularly upon vaccination against foot-and-mouth diseases with Soviet vaccine TF-130 (Ruchljada et al. 1973). As regards the immunity to trichophytosis, the possible effects of concurrent administration of trichophytic vaccine and antibiotics have not been studied in detail. Our challenge experiments including 147 vaccinated calves and 43 non-vaccinated controls contribute to a better understanding of this question.

It is a well-known fact that almost all antibiotics interfere, to a higher or lower degree, with the immune response. The most active of them in this sense is chloramphenicol (Bier et al. 1981). This also became apparent in our present study: some calves treated with chloramphenicol at the time of vaccination against trichophytosis proved less resistant to experimental infection with $T$. verrucosum culture than vaccinated animals receiving no chloramphenicol treatment. Immunosuppressive effects were also observed in some calves treated with Biopran, a preparation containing apramycin. On the other hand, penicillin, streptomycin and tetracycline which were regarded by Vrtiak (1990) as potential immunosuppressors did not exert any immunosuppressive effects in our study. Similar results were recorded by us also for Tylan and Duon.

The findings reported here are of value particularly to veterinary practice in the field. Prophylactic vaccination against trichophytosis is generally carried out 

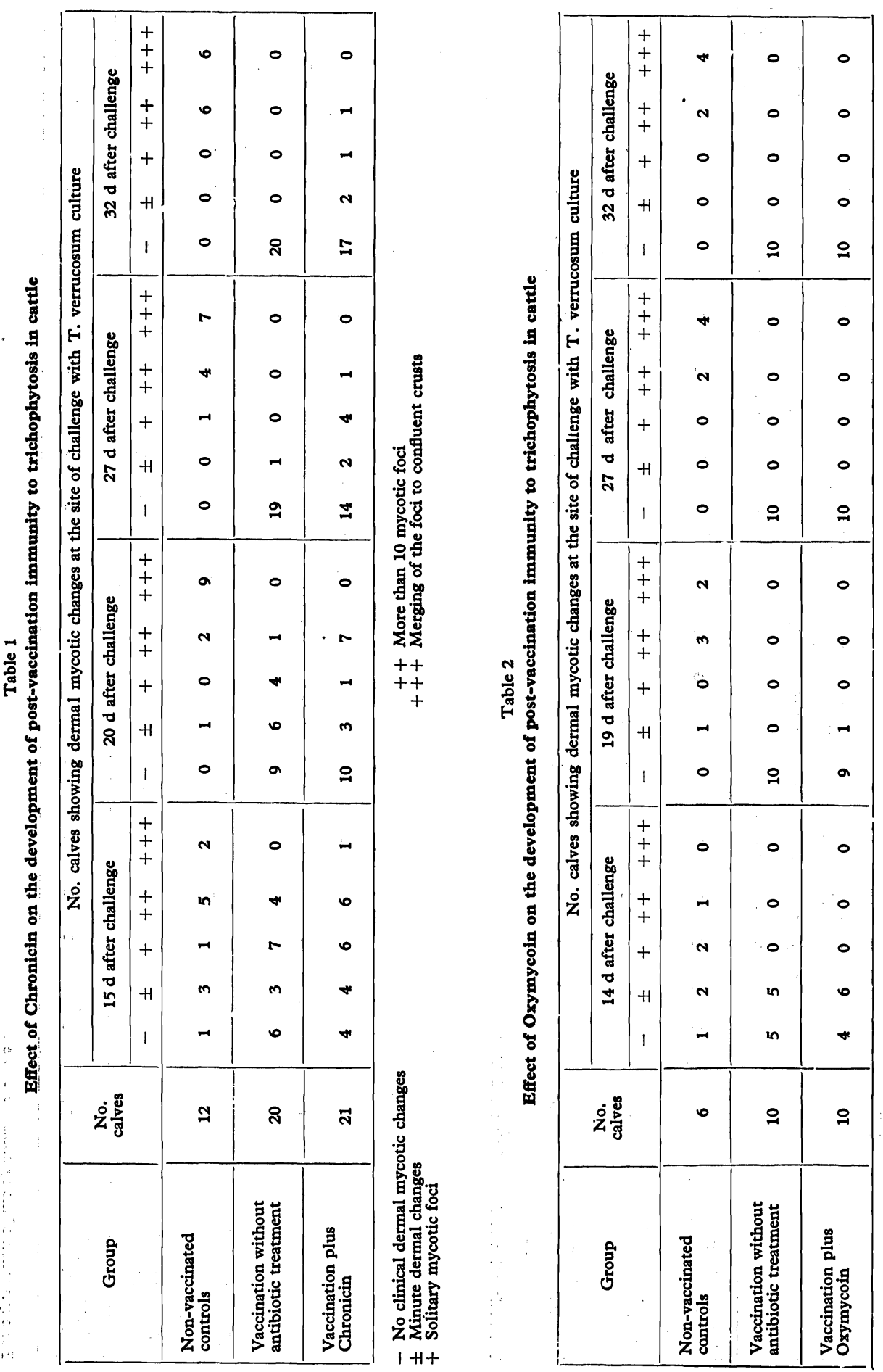

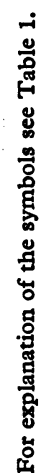



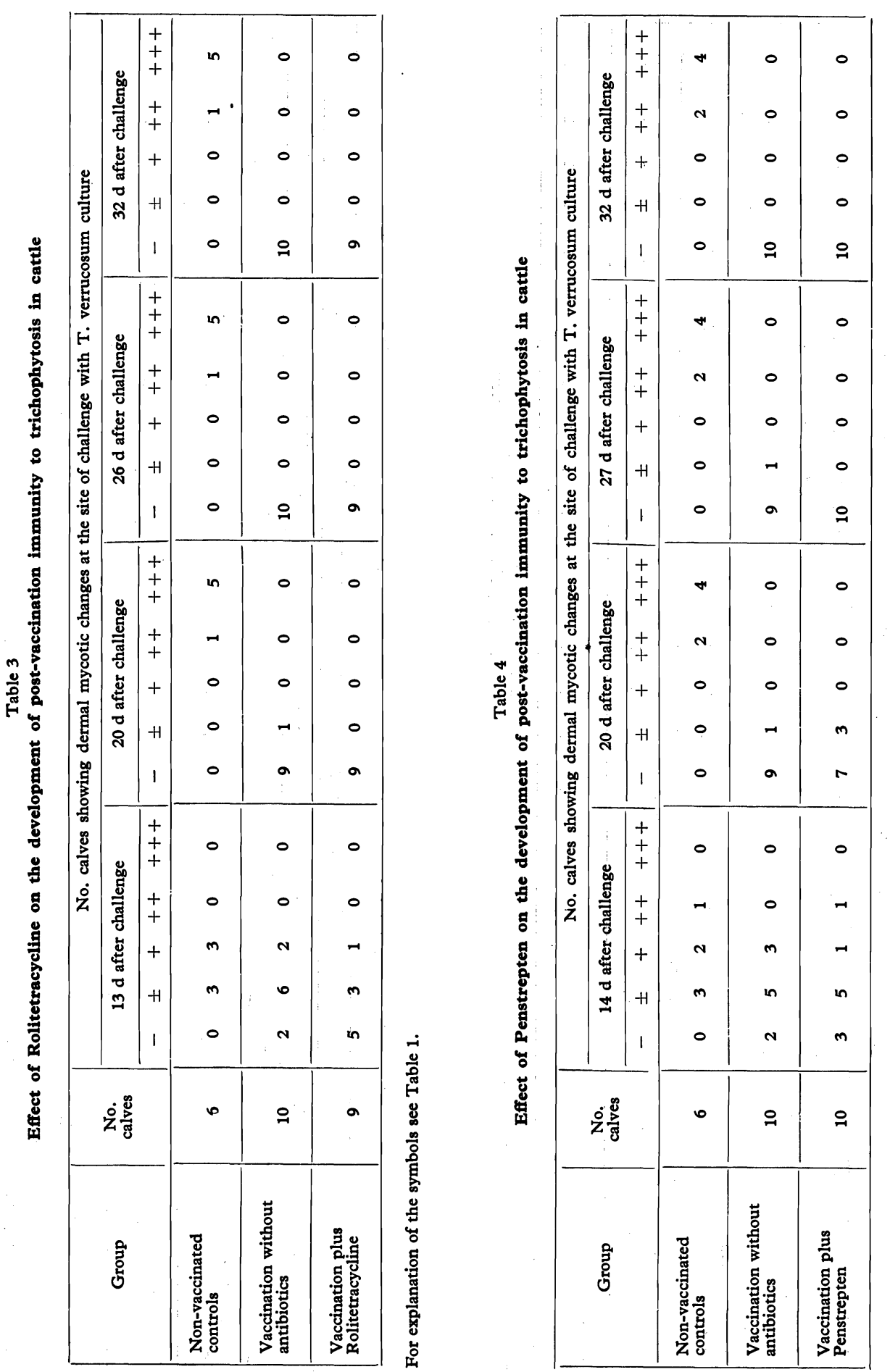

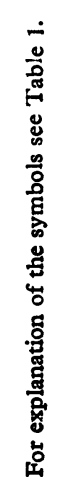



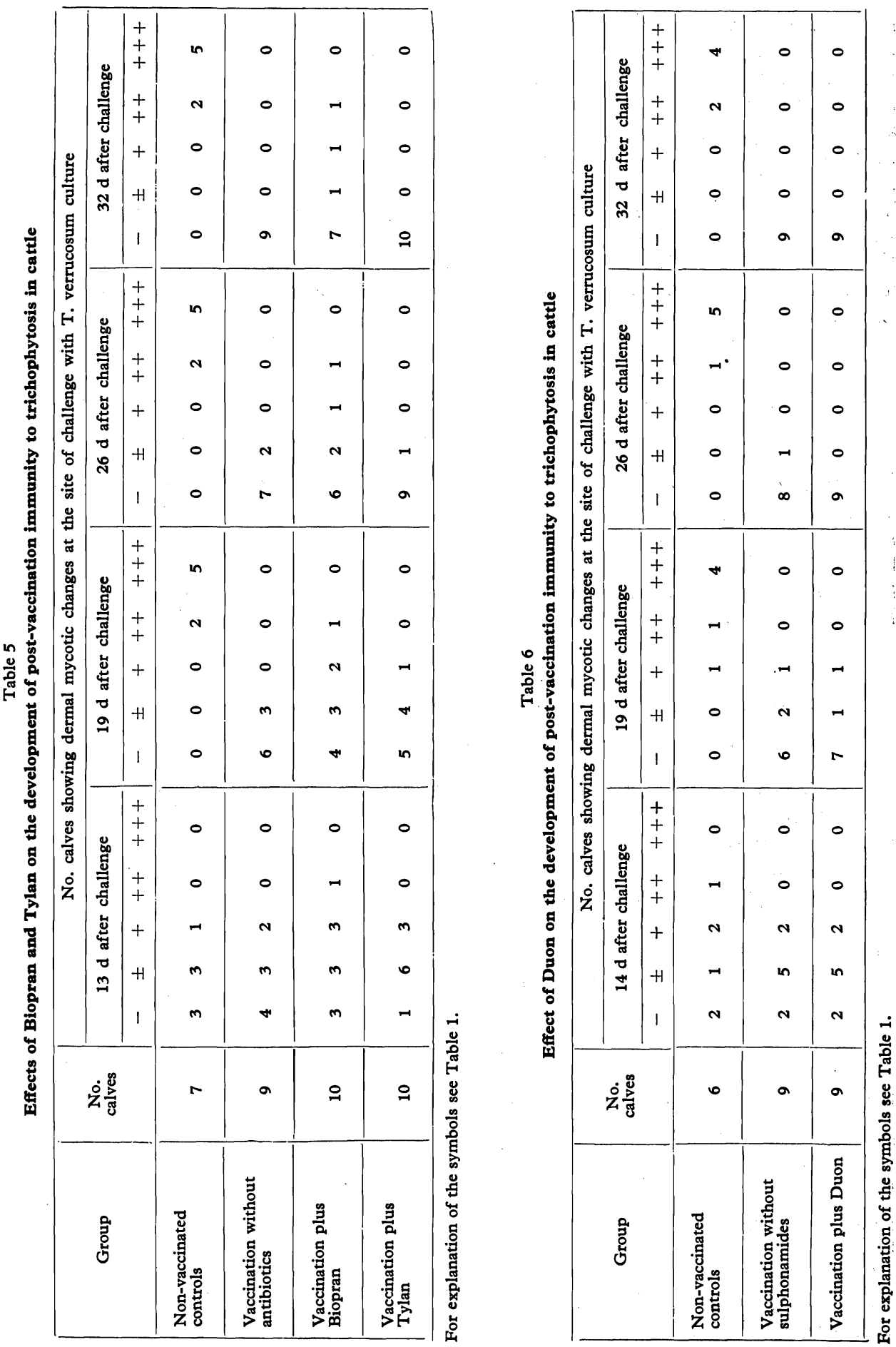
in calves between 1 and 2 months of age, i. e. at a time during which respiratory and intestinal diarrhoeal infections of these animals are a frequent problem, often making treatment with antibiotics and sulphonamides inevitable. From our results it appears that chloramphenicol and apramycin are less suited for concurrent administration with antitrichophytic vaccine than antibiotic preparations containing penicillin, streptomycin (these two antibiotics were likewise found by Poljakov (1981) to exert no immunosuppressive effects in calves vaccinated with TF-130), tylosine, oxytetracycline or rolitetracycline or than sulphonamide-containing Duon. However, further studies along this line are needed to confirm the present results. They should be carried out on a larger number of animals and should cover different lengths of time elapsing between vaccination and antibiotic treatment.

\section{Vliv antibiotik a sulfonamidů na postvakcinační imunitu proti trichofytóze u skotu}

Telata, ošetřená $\mathbf{v}$ době vakcinace proti trichofytóze chloramfenikolem nebo apramycinem, byla $\mathrm{k}$ experimentální infekci kulturou Trichophyton verrucosum méně resistentní než telata vakcinovaná, ale neošetřená těmito antibiotiky. U antibiotických př́ipravků, obsahujících penicilin, streptomycin, oxytetracyklin, rolitetracyklin, tylosin a sulfonamid nebyl imunosupresivní vliv na postvakcinační imunitu prokázán.

\section{Влияние антибиотиков и сүльфонамидов на поствакцинационный иммүнитет к трихофитозу у крупного рогатого скота}

Телята, принимавшие в период вакцинации против трихофитоза хлорамфеникол или апрамицин, отличались по отношению к экспериментальной инфекции культурой Trichophyton verrucosum меньшей сопротивляемостью по сравнению с вакцинированными но не принимавшими упомянутые антибиотики телятами. У антибиотическйх препаратов, содержащих пенициллин, стрептомицин, окситетрациклин, ропитетрациклин, тилозин и сульфонамид, иммүносупрессивное влияние на поствакцинационный иммунитет не было установлено.

\section{References}

BIER, O. G.- DA SILVA, W. D.-GÖTZE, D.-MOTA, I.: Fundamentals of immunology. Springer-Verlag, New York, 1981

GOROBEC, A.: Opyt ozdorovlenija chozjajstv ot striguščego lišaja. Veterinarija (Moskva), 1972, (10): $69-70$

KANJUKA, A. I.-ŠUTIAK, V.: O niektorých problémoch pri použivaní antibiotík vo veterinárnej praxi. Veterinářstvi, 40, 1990: 206-207

NOUZA, K.-JOUN, C.: Imunologie zdraví a nemoci. Avicenum, Praha, 1987

POLJAKOV, I. D.: Vlijanije povtornych immunizacij vakcinoj TF-130 (VIEV) na obščee kliničeskoe sostojanie i sensibilizaciju teljat. Bjul. Vses. Nauč. Issl. Inst. Exp. Vet., 42, 1981: 35-38

RUCHLJADA, V. V. - NIKOLAEV, S. M.-SUTJUK, V. K.: Effektivnost' specifičeskoj profilaktiki trichofitii. Veterinarija (Moskva), 1973, (6): 54-56

VRTIAK, O. J.: Význam imunosupresie. Veterinářství, 40, 1990: 53-57 